\title{
Weight-loss and surface roughness of enamel after microabrasion procedure with different agents
}

\author{
Perda de peso e rugosidade da superfície do esmalte após procedimento de \\ microabrasão com diferentes agentes
}

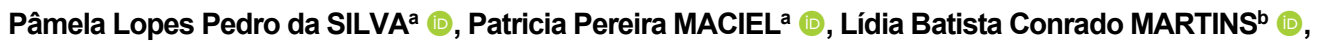 \\ Fabíola Galbiatti de CARVALHO ${ }^{\circledR}\left(\mathbb{D}\right.$, Rogério Lacerda dos SANTOS ${ }^{c} \mathbb{B}$, Eliton Souto de MEDEIROS ${ }^{d}(\mathbb{D}$, \\ Hugo Lemes CARLO ${ }^{\text {* }}$ (i) \\ aUFPB - Universidade Federal da Paraíba, Centro de Ciências da Saúde, João Pessoa, PB, Brasil \\ bUFJF - Universidade Federal de Juiz de Fora, Faculdade de Odontologia, Juiz de Fora, MG, Brasil \\ 'UFJF - Universidade Federal de Juiz de Fora, Instituto de Ciências da Saúde, Governador Valadares, MG, Brasil \\ dUFPB - Universidade Federal da Paraíba, Centro de Tecnologia, João Pessoa, PB, Brasil
}

How to cite: Silva PLP, Maciel PP, Martins LBC, Carvalho FG, Santos RL, Medeiros ES, et al. Weight-loss and surface roughness of enamel after microabrasion procedure with different agents. Rev Odontol UNESP. 2021;50:e20210020.

https://doi.org/10.1590/1807-2577.02021

\begin{abstract}
Resumo
Introdução: A microabrasão do esmalte é realizada através da abrasão da superfície do mesmo, apresentando-se como um procedimento rápido, prático e eficiente. Objetivo: Avaliar a perda de peso e o aspecto superficial do esmalte após procedimentos de microabrasão com agentes comerciais e não comerciais. Material e método: Oitenta incisivos bovinos foram divididos em quatro grupos $(\mathrm{n}=10)$ : Opalustre ${ }^{\mathrm{TM}}(6,6 \% \mathrm{HCl}+$ carboneto de silício); Whiteness $\mathrm{RM}^{\mathrm{TM}}(6 \% \mathrm{HCl}+$ carboneto de silício); $37 \% \mathrm{H} 3 \mathrm{PO} 4$ + pedra-pomes e $10 \% \mathrm{HCl}$ + pedra-pomes. $\mathrm{O}$ tratamento foi realizado em 15 aplicações de 10s de duração. A perda de peso do esmalte foi determinada pela diferença de peso antes e depois da microabrasão. As superfícies foram analisadas por equipamento de rugosidade superficial e microscopia eletrônica de varredura. Os dados foram submetidos ao teste T-pareado, ANOVA one-way e teste de Tukey $(\alpha=0,05)$. Resultado: Foi observada perda de peso significativa para todos os grupos, a diferença na perda de peso variou de $-0,037 \pm 0,012$ para o grupo $37 \% \mathrm{H} 3 \mathrm{PO} 4$ a $-0.054 \pm 0.009$ para o grupo $6.6 \% \mathrm{HCl}$. Houve um aumento significativo na rugosidade da superfície para todos os grupos e o grupo $10 \% \mathrm{HCl}$ apresentou os resultados mais baixos $(0,65 \pm 0,09)$. Foram observados diferentes padrões de morfologia do esmalte por meio de imagens MEV. Conclusão: Os agentes não comerciais resultaram na menor perda de estrutura do esmalte $(37 \%$ H3PO4) e na rugosidade superficial $(10 \% \mathrm{HCl})$.
\end{abstract}

Descritores: Microabrasão do esmalte; desgaste dentário; rigidez da superfície; agentes de microabrasão.

\begin{abstract}
Introduction: Enamel microabrasion is achieved by abrasion of the enamel surface and it is a quick, practical and efficient procedure. Objective: It was assessed the weight loss and surface aspect of enamel after microabrasion procedures with commercial and mixtures made in-office. Material and method: Eighty bovine incisors were divided into four groups $(\mathrm{n}=10)$ : Opalustre ${ }^{\mathrm{TM}}\left(6.6 \% \mathrm{HCl}+\right.$ silicon carbide); Whiteness $\mathrm{RM}^{\mathrm{TM}}(6 \% \mathrm{HCl}+$ silicon carbide); $37 \% \mathrm{H} 3 \mathrm{PO} 4$ + pumice and $10 \% \mathrm{HCl}+$ pumice. Treatment was performed by 15 applications of $10 \mathrm{~s}$ duration. The enamel weight loss was determined by the difference in weight before and after the microabrasion. The surfaces were analyzed by a surface roughness equipment and scanning electron microscopy. Data were submitted to paired-T test, one-way ANOVA and Tukey tests $(\alpha=0.05)$. Result: It was observed significantly weight loss for all groups. The difference in weight loss ranged from $0.037 \pm 0.012$ for group $37 \%$ H3PO4 and from $0.054 \pm 0.009$ for group $6,6 \% \mathrm{HCl}$. There was a significant increase in surface roughness for all groups and $10 \% \mathrm{HCl}$ group showed the lower results $(0.65 \pm 0.09)$. It was observed different patterns of enamel morphology by SEM images. Conclusion: The in-office mixtures resulted in the lowest enamel structure loss (37\% H3PO4) and the lowest surface roughness $(10 \% \mathrm{HCl})$.
\end{abstract}

Descriptors: Enamel miroabrasion; tooth wear; surface roughness; microabrasion agents. 


\section{INTRODUCTION}

Enamel microabrasion was originally developed by Croll, Cavanaugh in $1986^{1}$, for the removal of fluorotic enamel stains, but nowadays it has become accepted as a conservative and nonrestorative method to improve the appearance of teeth with superficial white, yellow and brown enamel stains resulting from hypoplasia, opacities, post-orthodontic treatment demineralization and fluorosis ${ }^{2,3}$. Its mechanism of action consists of the chemical activity produced by an acid associated with the mechanical action of an abrasive that will simultaneously erode and abrade the enamel surface, resulting in minimal loss of the outermost layer of enamel ${ }^{3,4}$.

The success of this technique depends largely on the correct indication with regard to etiology, depth and pattern of enamel staining 5,6 . Furthermore, the amount of enamel wear depends on the interplay of various factors such as the type of acid used and its concentration, extent and duration of applications, with or without the use of mechanical action 7,8 .

Several microabrasion techniques have been proposed using different concentrations and types of acid ${ }^{9,10}$. Several studies investigated microabrasion with $18 \%$ hydrochloric acid ${ }^{4,5,9-13}$ because it was the concentration recommended by Croll, Cavanaugh ${ }^{1}$. However, some studies have shown that $18 \%$ hydrochloric acid can cause damage to periodontal tissues that surround and support the teeth ${ }^{3,9}$. Thus, agents with a lower concentration of hydrochloric acid (6- 6.6 and $10 \%$ ), which may be available commercially or as a mixture made in-office, have demonstrated satisfactory results $3,4,14,15$. Other studies have also shown favorable results of an in-office agent manipulated with $37 \%$ phosphoric acid and pumice $6,9,16$.

Although, clinically, the microabrasion procedure is capable of removing stains and producing a smooth and shiny surface, microscopically it can remove the enamel ions by acid demineralization and a porous enamel may be formed, causing an increase in surface roughness and favoring colonization by bacteria and formation of carious lesions $7,14,17$. Based on the foregoing, previous studies have evaluated the amount of enamel loss and surface roughness after the microabrasion procedure $9,14,18$. However, to date, there is little information about the quantification (per weight) of enamel loss after treatment with microabrasion agents.

Therefore, the purpose of this study was to compare the weight loss, surface roughness and surface aspect of bovine enamel after microabrasion procedures using different agents (two commercial and two mixtures made in-office) with different concentrations and composition of acids and abrasives particles, testing the hypothesis that the agents could produce similar surface and enamel loss.

\section{MATERIAL AND METHOD}

\section{Specimen Preparation}

Eighty recently extracted bovine incisors were selected, cleaned and stored in distilled water at $4^{\circ} \mathrm{C}$ until use. The enamel surfaces were carefully examined with a stereomicroscope $(40 \mathrm{X}$ magnification), for the presence of any enamel developmental defect or irregularity. The coronary portion was separated ( $1 \mathrm{~mm}$ below of cement-enamel junction) using a double-face diamond disc (KG Sorensen Ind. Com. Ltda. - Barueri, São Paulo, SP, Brazil). The pulp was removed, and the pulp chamber filled with acrylic resin (Vipi Flash - Pirassununga, SP, Brazil). 


\section{Microabrasion Procedures}

The microabrasion agents investigated in the study are shown in Table 1. Samples were assigned to 4 treatment groups $(n=10)$, for each test, according to the abrasive agent used. Two commercial pastes (Opalustre - Ultradent Products Inc, South Jordan, UT, USA and Whiteness RM - FGM, Joinville, SC, Brazil) and two mixtures made in-office $\left(37 \% \mathrm{H}_{3} \mathrm{PO}_{4}+\right.$ pumice and $10 \% \mathrm{HCl}$ + pumice) were used.

In order to standardize the amount of abrasive paste applied to each sample, commercial agents were transferred from their original packaging to an individual disposable $1 \mathrm{~mL}$ hypodermic syringe (Injex - Ourinhos, SP, Brazil). The mixtures made in-office using $\mathrm{HCl}$ and $\mathrm{H}_{3} \mathrm{PO}_{4}$ were prepared with equal parts of acid and pumice, measured with a metering spoon $(0.18 \mathrm{~g})^{18}$ and were transferred to the individual disposable $1 \mathrm{~mL}$ hypodermic syringe. The amount of microabrasive agents used was standardized at $0.04 \mathrm{~mL}$ of each agent per application.

The crown surface area delimited for microabrasion procedures was $5 \mathrm{~mm}^{2}$ and the remaining coronal portion was isolated using nail varnish (Risque, Taboão da Serra, SP, Brazil). For all groups, the same application technique was used: application of abrasive agent using rubber cup (KG Sorensen, Cotia, SP, Brazil) mounted in a slow-speed handpiece for 10s, followed by tap water washing for 10s. Fifteen applications were performed for each sample in each group. One rubber cup was used for each sample. Only one calibrated operator performed the microabrasion procedures to avoid a difference in pressure during treatments. After microabrasion procedures, the excess agent was removed with sterile gauze and the sample was rinsed for $20 \mathrm{~s}$ and submitted to ultrasonic bath for 10min (USC1400 - Unique Ind e Com Ltda, São Paulo, SP, Brazil).

Table 1. Microabrasion agents investigated in the study*

\begin{tabular}{|c|c|c|}
\hline Material & $\begin{array}{c}\text { Manufacturer } \\
\text { (batch number) }\end{array}$ & Composition \\
\hline Opalustre & $\begin{array}{l}\text { Ultradent Products Inc. } \\
\text { (South Jordan, UT, USA) } \\
\text { (B307B) }\end{array}$ & $\begin{array}{l}6.6 \% \text { hydrochloric acid, water, silicon } \\
\text { carbide }(20-60 \mu \mathrm{m})\end{array}$ \\
\hline Whiteness RM & $\begin{array}{c}\text { FGM } \\
\text { (Joinville, SC, Brazil) } \\
(80602)\end{array}$ & $\begin{array}{l}6 \% \text { hydrochloric acid, deionized water, } \\
\text { propylene glycol, thickeners, silicon } \\
\text { carbide (with approximately } 82 \mu \mathrm{m} \text { ) }\end{array}$ \\
\hline Condac 37 & $\begin{array}{c}\text { FGM } \\
\text { (Joinville, SC, Brazil) } \\
\text { (150612) } \\
\text { Merck Millipore }\end{array}$ & $37 \%$ phosphoric acid \\
\hline Hydrochloric acid & $\begin{array}{c}\text { (Merck KGaA, Darmstadt, HE, } \\
\text { Germany) } \\
(4805922500) \\
\text { SS White }\end{array}$ & $10 \%$ hydrochloric acid \\
\hline Pumice & $\begin{array}{c}\text { (Rio de Janeiro, RJ, Brazil) } \\
(052)\end{array}$ & Pumice extra-fine $(0.8-3.0 \mu \mathrm{m})$ \\
\hline
\end{tabular}

*According to manufacturers' information. 


\section{Weight Loss Method}

Samples were analyzed by the weight loss method to measure the amount of enamel loss by microabrasion procedures ${ }^{19}$. Immediately before microabrasion, each sample was weighed on a digital balance (AG 200 - Gehaka, São Paulo, SP, Brazil) with accuracy of 0.0001g. After microabrasion procedures, samples were washed with distilled water, the excess was removed with absorbent paper and they were cleaned with air stream at a distance of $10 \mathrm{~cm}$ for $40 \mathrm{~s}$ and reweighed ${ }^{19}$. For each group, the difference between the values of weight ( $\mathrm{g}$ ) before and after the microabrasion procedure was determined as the enamel weight loss value.

\section{Surface Roughness}

Surface roughness was measured with a roughness measuring device (Surftest SJ 301 Mitutoyo, Tokyo, Japan). The surface roughness was characterized by Ra $(\mu \mathrm{m})$. Ra is an arithmetic average of the peaks and valleys of the surface of the specimen, it is recorded as absolute values within the evaluation length and is generally expressed in units of height. For each sample, three measurements were made in different directions, with a cutoff value of $0.8 \mathrm{~mm}$. A diamond tip with a radius of $2 \mathrm{~mm}$ was used and constant speed of $0.05 \mathrm{~mm} / \mathrm{s}$ and $0.7 \mathrm{~m} / \mathrm{N}$. The cutoff value was set at $0.8 \mathrm{~mm}$ in the Gauss filter. The mean Ra values were calculated using the following formula when the roughness curve is expressed in $y=f(x)$ and $L$ is the reference length (Equation 1 ):

$$
R a=\frac{1}{L} \int_{0}^{L}|f(x)| d x
$$

The Ra measurements were made before and after the microabrasion treatment.

\section{Scanning Electron Microscopy (SEM) Evaluation}

Three samples from each group were randomly selected for SEM analysis. Three additional teeth were used as control for examination of enamel morphology without the microabrasion procedure. After the samples were dehydrated with silica gel in a container at $40^{\circ} \mathrm{C}$ for three days ${ }^{17}$, they were mounted on an aluminum stub and sputter-coated with platinum-gold (SCD050 - Baltec, Balzers, Liechtenstein) and examined under SEM (Leo 1430 - Zeiss, Oberkochen, BW, Germany). Images were obtained at 2.000x and 4.000x magnification.

\section{Statistical Analysis}

Data analysis was performed with the GraphPad Instat version 2.0 (GraphPad software program, San Diego, CA, USA) with $5 \%$ of significance $(\alpha=0.05)$. All the variables tested satisfied the assumptions of equality and normal distribution (Bartlett and Kolmogorov-Smirnov tests, respectively). The paired-T test was used to compare the enamel weight loss and surface roughness before and after the microabrasion procedures. One-way ANOVA and Tukey tests were carried out for statistical comparisons of enamel weight loss and surface roughness among groups.

\section{RESULT}

Table 2 shows the average weight before and after the microabrasion procedure and enamel weight loss. There was a significant decrease in weight values after the microabrasion procedure 
for all groups ( $\mathrm{p}=0.004)$. For enamel weight loss, all groups showed negative values indicating loss of enamel structure. The $37 \% \mathrm{H}_{3} \mathrm{PO}_{4}$ group showed lower enamel weight loss in comparison with the other groups $(\mathrm{p}=0.002)$. The $6 \% \mathrm{HCl}+$ silicon carbide group showed intermediate enamel weight loss values. There was no statistical difference in enamel weight loss among $6.6 \%$ $\mathrm{HCl}+$ silicon carbide group, $6 \% \mathrm{HCl}+$ silicon carbide group and $10 \% \mathrm{HCl}+$ pumice groups $(\mathrm{p}=0.06)$.

Table 2. Enamel weight loss measurements before and after microabrasion procedures expressed in grams (g) (mean \pm standard deviation)

\begin{tabular}{|c|c|c|c|}
\hline Microabrasion agente & $\begin{array}{l}\text { Weight before } \\
\text { (g) }\end{array}$ & $\begin{array}{l}\text { Weight after } \\
\text { (g) }\end{array}$ & $\begin{array}{c}\text { Enamel weight loss } \\
\text { (g) }\end{array}$ \\
\hline $6.6 \% \mathrm{HCl}+$ silicon carbide & $4.114 \pm 0.849^{A} *$ & $4.060 \pm 0.849^{\mathrm{B}}$ & $-0.054 \pm 0.0099^{a * *}$ \\
\hline $6 \% \mathrm{HCl}+$ silicon carbide & $4.201 \pm 0.652^{\mathrm{A}}$ & $4.156 \pm 0.650^{\mathrm{B}}$ & $-0.045 \pm 0.011^{\mathrm{a}, \mathrm{b}}$ \\
\hline $37 \% \mathrm{H}_{3} \mathrm{PO}_{4}+$ pumice & $4.139 \pm 0.934^{\mathrm{A}}$ & $4.102 \pm 0.931^{\mathrm{B}}$ & $-0.037 \pm 0.012^{b}$ \\
\hline $10 \% \mathrm{HCl}+$ pumice & $4.062 \pm 0.759 \mathrm{~A}$ & $4.010 \pm 0.745^{\mathrm{B}}$ & $-0.052 \pm 0.017^{a}$ \\
\hline
\end{tabular}

*Same uppercase letters indicate that there was no significant difference between weight before and after microabrasion procedure for each agent (paired-t- test, $p>0.05$ ). ${ }^{* *}$ Same lowercase letters indicate that there was no significant difference in enamel weight loss among microabrasion agents (Two-way ANOVA and Tukey test, $\mathrm{p}>0.05$ ).

Table 3 shows the mean enamel surface roughness before and after the microabrasion procedure. There was a significant increase in surface roughness values after the microabrasion procedure for all groups $(\mathrm{p}=0.03)$. Before the microabrasion procedure there was no significant difference in surface roughness among the groups. However, after microabrasion $6.6 \% \mathrm{HCl}+$ silicon carbide group, $6 \% \mathrm{HCl}+$ silicon carbide group and $37 \% \mathrm{H}_{3} \mathrm{PO}_{4}+$ pumice groups showed no significant difference among them, only the $10 \% \mathrm{HCl}+$ pumice group had lower surface roughness value compared with other groups.

Table 3. Surface roughness values $(R a)$ expressed in $\mu \mathrm{m}$ (mean \pm standard deviation) before and after microabrasion procedures

\begin{tabular}{|c|c|c|}
\hline Microabrasion agent & $\begin{array}{l}\text { Surface Roughness before } \\
(\mu \mathrm{m})\end{array}$ & $\begin{array}{c}\text { Surface Roughness after } \\
(\mu \mathrm{m})\end{array}$ \\
\hline $6.6 \% \mathrm{HCl}+$ silicon carbide & $0.25 \pm 0.04 \mathrm{~A}, \mathrm{a} *$ & $1.03 \pm 0.06^{\mathrm{B}, \mathrm{a} * *}$ \\
\hline $6 \% \mathrm{HCl}+$ silicon carbide & $0.23 \pm 0.02^{\mathrm{A}, \mathrm{a}}$ & $1.17 \pm 0.11^{\mathrm{B}, \mathrm{a}}$ \\
\hline $37 \% \mathrm{H}_{3} \mathrm{PO}_{4}+$ pumice & $0.20 \pm 0.02^{\mathrm{A}, \mathrm{a}}$ & $1.22 \pm 0.21^{\mathrm{B}, \mathrm{a}}$ \\
\hline $10 \% \mathrm{HCl}+$ pumice & $0.21 \pm 0.01^{\mathrm{A}, \mathrm{a}}$ & $0.65 \pm 0.09 \mathrm{~B}, \mathrm{~b}$ \\
\hline
\end{tabular}

*Same uppercase letters indicate that there was no significant difference between surface roughness before and after microabrasion procedure for each agent (paired-t- test, $p>0.05$ ). ${ }^{* *}$ Same lowercase letters indicate that there was no significant difference in surface roughness values among microabrasion agents (Two-way ANOVA and Tukey test, $\mathrm{p}>0.05$ ).

Figure 1 shows the SEM analysis. The microabrasion agents showed different patterns of enamel morphology. Control group specimens (without undergoing the microabrasion procedure) showed a smooth enamel surface (Figure $1 \mathrm{~A}$ and $\mathrm{B}$ ). The surface morphology of the $6.6 \% \mathrm{HCl}+$ silicon carbide group showed a selective etching pattern in the interprismatic region (Figure 1C and D). Microabrasion with 6\% $\mathrm{HCl}+$ silicon carbide agent showed a surface with considerable irregularity and discrete enamel dissolution (Figure 1E and F). Microabrasion in $37 \% \mathrm{H}_{3} \mathrm{PO}_{4}$ + pumice group, showed a morphological pattern of etched enamel, characterized by the dissolution of interprismatic enamel (Figure $1 \mathrm{G}$ and $\mathrm{H}$ ) and the surface morphology of the $10 \% \mathrm{HCl}+$ pumice group was slightly irregular, with a sandy appearance due to homogeneous dissolution of the enamel surface (Figure 1I and J). 

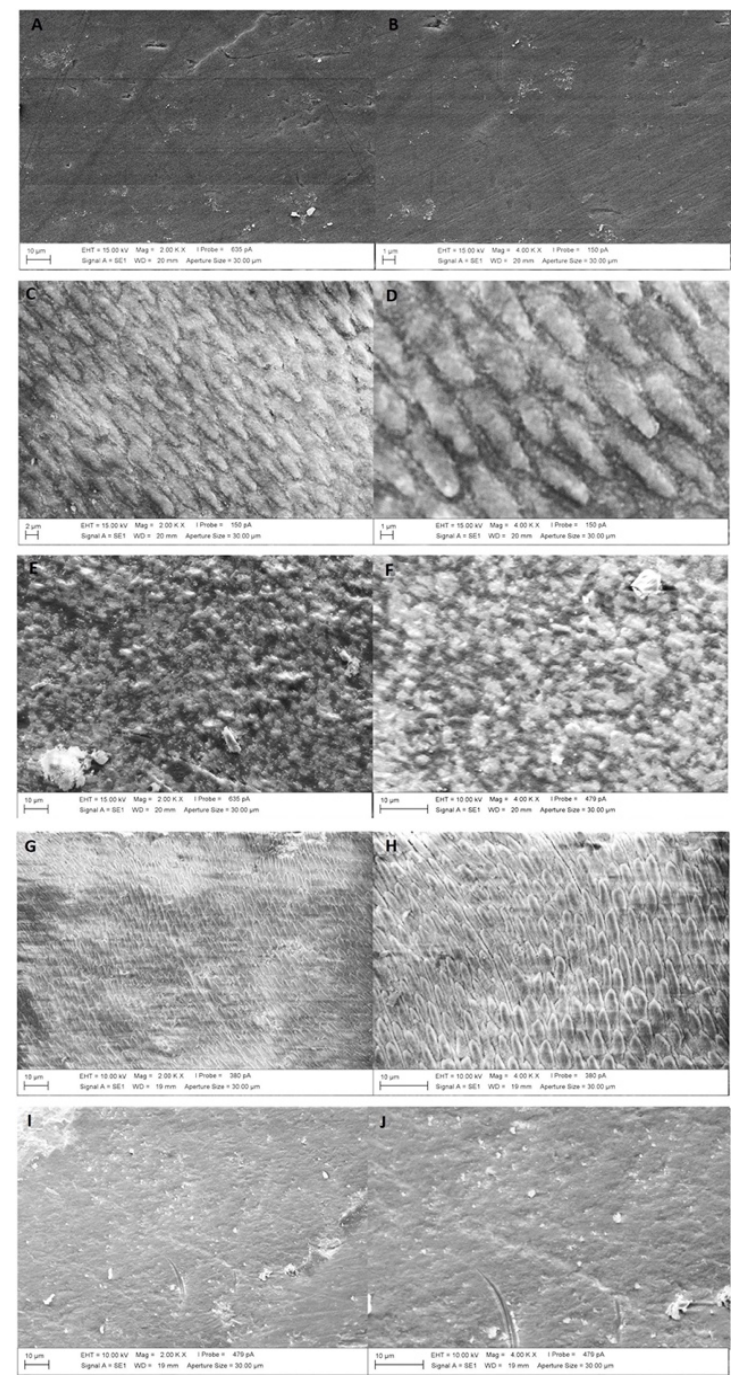

Figure 1. SEM micrographs of the enamel morphology after microabrasion. $A(x 2.000)$ and $B(x 4.000)-$ control group showing a smooth surface; $\mathrm{C}(\mathrm{x} 2.000)$ and $\mathrm{D}(\mathrm{x} 4.000)-6.6 \% \mathrm{HCl}+$ silicon carbide group showing selective etching pattern in the interprismatic region; $E(x 2.000)$ and $F(x 4.000)-6 \% \mathrm{HCl}+$ silicon carbide group showing surface with discrete dissolution of enamel; $\mathrm{G}(\mathrm{x} 2.000)$ and $\mathrm{H}(\mathrm{x} 4.000)-37 \% \mathrm{H} 3 \mathrm{PO} 4+$ pumice group showing surface with selective etching pattern in the interprismatic region. I (x2.000) and J (x4.000) $10 \% \mathrm{HCl}+$ pumice group showing surface slightly irregular with a sandy appearance.

\section{DISCUSSION}

Previous studies have investigated the effect of microabrasion agents with different concentrations and compositions of acids on the enamel surface ${ }^{3,6,9,18}$. However, there has been little investigation into the quantification of weight loss of enamel. The hypothesis tested was not accepted since there were differences in enamel weight loss, surface roughness and surface aspect among the microabrasion agents tested.

The weight loss of enamel by the microabrasion technique may be associated with alterations in enamel composition, such as the inorganic components of hydroxyapatite, components of organic matrix and water loss. The diffusion of acids into the enamel structure can lead to cumulative loss of calcium ions by dissolution of the apatite mineral ${ }^{14}$ and alterations of the enamel proteins that may increase the accessibility of acids to enamel pores or decrease the iondiffusion processes inside the structure ${ }^{20}$. Water in enamel is important for a variety of properties, including optical and mechanical properties, transport and reactivity ${ }^{21}$. Thus, the change in the original ratio between the organic and inorganic components and water of enamel 
can increase its solubility; and the weight loss of enamel structure can decrease its resistance to acid attack ${ }^{22}$.

During the technique, the abrasive action of the particles of the acidic material corroborate to morphological changes on the surface of the dental enamel. Such alteration gives rise to the socalled "corrosion effect", attributing to the enamel particular histological and optical characteristics ${ }^{23}$. Besides that, the erosive and abrasive potential of microabrasion agents depends on several parameters: type, concentration and $\mathrm{pH}$ of acid, abrasive particles, time of application, type of instrument used (manual or mechanical) and pressure during application $7,8,14,24$. Unfortunately, these factors are poorly described in the majority of studies, making it difficult to compare their results. In the present study agents with different types and concentration of acids and abrasive particles were investigated for microabrasion procedures, but the same technique was used for application of agents, in order to standardize the effects of the technique on enamel and make a more accurate comparison for each product. Therefore, the technique established by the manufacturer of $6 \% \mathrm{HCl}+$ silicon carbide (15 applications of $10 \mathrm{~s}$ ) was used, since no specific technique was indicated for the other agents.

After the microabrasion procedure, all agents showed a decrease in enamel weight values (Table 2). This result was expected because during the microabrasion procedure, the acid used is able to penetrate into the enamel structure and cause displacement of hydroxyapatite ions ${ }^{9,17}$. This may increase the level of enamel porosity, facilitating acid transport and further demineralization 9 ,17. Other studies have also reported loss of enamel structure by the microabrasion procedure $8,14,20$. However, the observed values are much lower than those obtained with a carbide bur 21,25 .

The results of enamel weight loss showed that the higher the concentration of hydrochloric acid, the higher was the weight loss of enamel (Table 2), probably due to the higher degree of demineralization caused by more concentrated acid. Paic et al. ${ }^{10}$ also reported that $6.6 \% \mathrm{HCl}$ removed significantly more enamel structure $\left(\mu \mathrm{g} \mathrm{Ca}{ }^{+2}\right)$ than $1.5 \% \mathrm{HCl}$ after $10,20,30$, and $40 \mathrm{~s}$ of application. The $37 \% \mathrm{H}_{3} \mathrm{PO}_{4}+$ pumice group showed the lowest weight loss $(-0.037 \mathrm{~g} \pm 0.012 \mathrm{~g})$. According to previous studies $9,24,25$ different acids promote different patterns of demineralization and morphological change, which could explain the distinct reactions of the specimens treated with phosphoric or hydrochloric acids. The phosphoric acid promotes a less aggressive decalcification ${ }^{25}$ and lower weight loss can occur in comparison with hydrochloric acid, which can dissolve the entire enamel surface after microabrasion ${ }^{25}$. In the study of Meireles et al. ${ }^{6}$ there was also a difference between enamel demineralization by $\mathrm{HCl}$ and $37 \% \mathrm{H}_{3} \mathrm{PO}_{4}$ after the microabrasion procedure; $18 \% \mathrm{HCl}$ showed $94.6 \pm 22.7(\mu \mathrm{m})$ depth of demineralization in comparison with $37 \% \mathrm{H}_{3} \mathrm{PO}_{4}$, which showed $48.0 \pm 17.8(\mu \mathrm{m})$.

In the present study, a significant increase in roughness values was shown for all groups after application of microabrasion agents (Table 3). This increase was suggested by Pini et al. ${ }^{18}$, where the author reports that the increase in the roughness of the enamel surface will suffer an increase in roughness regardless of the acidic concentration of the material used, whether phosphoric acid or hydrochloric acid with abrasive ${ }^{19}$. However, it was observed that enamel treated with $37 \%$ $\mathrm{H}_{3} \mathrm{PO}_{4}+$ pumice, $6.6 \% \mathrm{HCl}+$ silicon carbide and $6.0 \% \mathrm{HCl}+$ silicon carbide produced a rougher surface than enamel treated with $10 \% \mathrm{HCl}+$ pumice (Table 3 ). The highest concentration of hydrochloric acid (10\%) had the highest potential of enamel prism dissolution compared with lower concentrations, causing a non-selective etching pattern of enamel prisms and a homogeneous demineralization on the entire enamel surface, resulting in a smoother surface ${ }^{3,9,25}$. The SEM images demonstrated that the $10 \% \mathrm{HCl}+$ silicon carbide group (Figure 1 - I and J) showed a smoother, slightly irregular surface, with a sandy appearance in comparison with $6.6 \%$ $\mathrm{HCl}$ and $6 \% \mathrm{HCl}+$ silicon carbide groups (Figure $1 \mathrm{C}$ and D, E and F, respectively). The procedures performed in the $6.6 \% \mathrm{HCl}$ and $6 \% \mathrm{HCl}+$ silicon carbide groups showed a selective etching pattern in the interprismatic region and an irregular surface (Figure 1C and D, E and F). Similarly, 
the phosphoric acid group (Figure $1 \mathrm{G}$ and $\mathrm{H}$ ) had a selective enamel etching pattern with dissolution of the interprismatic region or center of prisms ${ }^{6,9,25}$, which could also promote irregularities and increase the surface roughness of enamel to the same extent as hydrochloric acid with 6 and $6.6 \%$ concentration $^{18}$.

The size and shape of abrasive particles in the microabrasive agents also can influence enamel roughness ${ }^{25}$. In the present study, the $6.6 \% \mathrm{HCl}$ agent contained $20-60 \mu \mathrm{m}$ silicon carbide particles, the $6 \% \mathrm{HCl}$ agent contained silicon carbide particles with approximately $82 \mu \mathrm{m}$, and 0.8 - $3.0 \mu \mathrm{m}$ pumice particles were used with the $37 \% \mathrm{H}_{3} \mathrm{PO}_{4}$ and $10 \% \mathrm{HCl}$ acids. The granulation of silicon carbide particles was of a larger size and more irregular shape than the pumice particles 24 . These characteristics could contribute to a smoother enamel surface layer ${ }^{25}$. However, the results of our study showed little influence of the size and shape of abrasive particles on roughness and weight loss of enamel, since the $10 \% \mathrm{HCl}+$ pumice group showed the smoothest surface, and the $37 \% \mathrm{H}_{3} \mathrm{PO}_{4}+$ pumice and $6 \% \mathrm{HCl}+$ silicon carbide groups showed the lowest weight loss measurements. The concentration and the type of acid may probably have exerted more influence on the enamel structure than the size and shape of abrasive particles.

Clinically, the polishing procedure is generally performed after the microabrasion technique to improve the tooth esthetics and prevent surface alterations ${ }^{3,14,18}$. However, in the present study this clinical step was not used because the real weight loss of enamel would be evaluated, and the polishing procedure could remove more sound enamel structure ${ }^{15,18}$.

The microabrasion technique is highlighted as a micro-invasive procedure and should be used with caution to avoid excessive tooth sound structure removal ${ }^{14}$. Based on these considerations and on the results of this study that the $37 \% \mathrm{H}_{3} \mathrm{PO}_{4}+$ pumice group showed the lowest weight loss of enamel and similar roughness values in comparison with the low concentration $\mathrm{HCl}$ agents, it can be suggested that the $37 \% \mathrm{H}_{3} \mathrm{PO}_{4}+$ pumice microabrasion technique may be a more promising alternative in clinical practice due to better control of the wear of the enamel surface. Furthermore, phosphoric acid is easily available in the dental office for routine use in bonding procedures, dispensing with the need to acquire other specific commercial products. In addition, for use it in microabrasion procedures it can be safer for both patients and professionals, because it is a weaker acid than $\mathrm{HCl}^{9}$.

\section{CONCLUSION}

All microabrasion agents investigated showed weight loss and increase in roughness values after the microabrasion procedure. The in-office mixtures resulted in the lowest enamel structure loss $(37 \% \mathrm{H} 3 \mathrm{PO} 4)$ and the lowest surface roughness $(10 \% \mathrm{HCl})$.

\section{ACKNOWLEDGEMENTS}

The authors thank Ultradent and FGM for supplying the materials used in this study.

\section{REFERENCES}

1. Croll TP, Cavanaugh RR. Enamel color modification by controlled hydrochloric acid-pumice abrasion. I. technique and examples. Quintessence Int. 1986 Feb;17(2):81-7. PMid:3457401.

2. Schmidlin PR, Göhring TN, Schug J, Lutz F. Histological, morphological, profilometric and optical changes of human tooth enamel after microabrasion. Am J Dent. 2003 Sep;16(Spec No):4A-8A. PMid:14674490. 
3. Celik EU, Yıldız G, Yazkan B. Comparison of enamel microabrasion with a combined approach to the esthetic management of fluorosed teeth. Oper Dent. 2013;38(5):E134-43. http://dx.doi.org/10.2341/12-317-C. PMid:23391032.

4. Sinha S, Vorse KK, Noorani H, Kumaraswamy SP, Varma S, Surappaneni H. Microabrasion using 18\% hydrochloric acid and 37\% phosphoric acid in various degrees of fluorosis - an in vivo comparision. Eur J Esthet Dent. 2013;8(3):454-65. PMid:23957044.

5. Olin PS, Lehner CR, Hilton JA. Enamel surface modification in vitro using hydrochloric acid pumice: an SEM investigation. Quintessence Int. 1988 Oct;19(10):733-6. PMid:2855889.

6. Meireles SS, Andre DA, Leida FL, Bocangel JS, Demarco FF. Surface roughness and enamel loss with two microabrasion techniques. J Contemp Dent Pract. 2009 Jan;10(1):58-65. http://dx.doi.org/10.5005/jcdp-10-1-58. PMid:19142257.

7. Wong FS, Winter GB. Effectiveness of microabrasion technique for improvement of dental aesthetics. Br Dent J. 2002 Aug;193(3):155-8. http://dx.doi.org/10.1038/sj.bdj.4801511. PMid:12213009.

8. Murphy TC, Willmot DR, Rodd HD. Management of postorthodontic demineralized white lesions with microabrasion: a quantitative assessment. Am J Orthod Dentofacial Orthop. 2007 Jan;131(1):27-33. http://dx.doi.org/10.1016/j.ajodo.2005.04.041. PMid:17208103.

9. Tong LS, Pang MK, Mok NY, King NM, Wei SH. The effects of etching, micro-abrasion, and bleaching on surface enamel. J Dent Res. 1993 Jan;72(1):67-71. http://dx.doi.org/10.1177/00220345930720011001. PMid:8418110.

10. Paic M, Sener B, Schug J, Schmidlin PR. Effects of microabrasion on substance loss, surface roughness, and colorimetric changes on enamel in vitro. Quintessence Int. 2008 Jun;39(6):517-22. PMid:19057750.

11. Price RBT, Loney RW, Doyle MG, Moulding MB. An evaluation of a technique to remove stains from teeth using microabrasion. J Am Dent Assoc. 2003 Aug;134(8):1066-71. http://dx.doi.org/10.14219/jada.archive.2003.0320. PMid:12956346.

12. Wang Q, Meng Q, Meng J. Minimally invasive esthetic management of dental fluorosis: a case report. J Int Med Res. 2020 Oct;48(10):300060520967538. http://dx.doi.org/10.1177/0300060520967538. PMid:33121307.

13. Romero MF, Babb CS, Delash J, Brackett WW. Minimally invasive esthetic improvement in a patient with dental fluorosis by using microabrasion and bleaching: a clinical report. J Prosthet Dent. 2018 Sep;120(3):323-6. http://dx.doi.org/10.1016/j.prosdent.2017.12.024. PMid:29724552.

14. Pliska BT, Warner GA, Tantbirojn D, Larson BE. Treatment of white spot lesions with ACP paste and microabrasion. Angle Orthod. 2012 Sep;82(5):765-9. http://dx.doi.org/10.2319/111611-710.1. PMid:22352382.

15. Mathias J, Kavitha S, Mahalaxmi S. A comparison of surface roughness after micro abrasion of enamel with and without using CPP-ACP: an in vitro study. J Conserv Dent. 2009 Jan;12(1):22-5. http://dx.doi.org/10.4103/0972-0707.53337. PMid:20379436.

16. Fragoso LSM, Lima DANL, de Alexandre RS, Bertoldo CES, Aguiar FHB, Lovadino JR. Evaluation of physical properties of enamel after microabrasion, polishing, and storage in artificial saliva. Biomed Mater. 2011 Jun;6(3):035001. http://dx.doi.org/10.1088/1748-6041/6/3/035001. PMid:21487176.

17. Fais LMG, Pinelli LAP, Adabo GL, Silva RHBT, Marcelo CC, Guaglianoni DG. Influence of microwave sterilization on the cutting capacity of carbide burs. J Appl Oral Sci. 2009 Nov-Dec;17(6):584-9. http://dx.doi.org/10.1590/S1678-77572009000600009. PMid:20027431.

18. Pini NIP, Lima DANL, Ambrosano GMB, da Silva WJ, Aguiar FHB, Lovadino JR. Effects of acids used in the microabrasion technique: Microhardness and confocal microscopy analysis. J Clin Exp Dent. 2015 Oct;7(4):e506-12. http://dx.doi.org/10.4317/jced.51416. PMid:26535098. 
19. Pini NIP, Lima DANL, Sundfeld RH, Ambrosano GMB, Aguiar FHB, Lovadino JR. Tooth enamel properties and morphology after microabrasion: an in situ study. J Investig Clin Dent. 2017 May;8(2):e12212. http://dx.doi.org/10.1111/jicd.12212. PMid:26997329.

20. Poorni S, Kumar RA, Shankar P, Indira R, Ramachandran S. Effect of $10 \%$ sodium ascorbate on the calcium: phosphorus ratio of enamel bleached with $35 \%$ hydrogen peroxide: an in vitro quantitative energy-dispersive X-ray analysis. Contemp Clin Dent. 2010 0ct;1(4):223-6. PMid:22114425.

21. Azzahim L, Chala S, Abdallaoui F. Role of enamel microabrasion associated with external bleaching in the management of patients with dental fluorosis. Pan Afr Med J. 2019 Oct;34:72. PMid:31819788.

22. Dalzell DP, Howes RI, Hubler PM. Microabrasion: effect of time, number of applications, and pressure on enamel loss. Pediatr Dent. 1995 May-Jun;17(3):207-11. PMid:7617497.

23. Nevárez-Rascón M, Molina-Frechero N, Edith-Adame, Almeida E, Soto-Barreras U, Gaona E, et al. . Effectiveness of a microabrasion technique using 16\% HCL with manual application on fluorotic teeth: A series of studies. World J Clin Cases. 2020 Feb;8(4):743-56. http://dx.doi.org/10.12998/wjcc.v8.i4.743. PMid:32149058.

24. Rodrigues MC, Mondelli RFL, Oliveira GU, Franco EB, Baseggio W, Wang L. Minimal alterations on the enamel surface by micro-abrasion: in vitro roughness and wear assessments. J Appl Oral Sci. 2013 Mar-Apr;21(2):112-7. http://dx.doi.org/10.1590/1678-7757201302117. PMid:23739863.

25. Silverstone LM, Saxton CA, Dogon IL, Fejerskov O. Variation in the pattern of acid etching of human dental enamel examined by scanning electron microscopy. Caries Res. 1975;9(5):373-87. http://dx.doi.org/10.1159/000260179. PMid:1055640.

\section{CONFLICTS OF INTERESTS}

The authors declare no conflicts of interest.

\section{${ }^{*}$ CORRESPONDING AUTHOR}

Hugo Lemes Carlo, UFJF - Universidade Federal de Juiz de Fora, Instituto de Ciências da Saúde, Departamento de Odontologia, Av. Dr. Raimundo Monteiro de Rezende, 330, sala 301, Centro, 35010-177 Governador Valadares - MG, Brasil, e-mail: hugo.carlo@ufjf.edu.br

Received: April 5, 2021

Accepted: September 1, 2021 